\section{History and Culture of Regal Pelargonium}

\author{
Marietta M. Loehrlein ${ }^{1}$ and \\ Richard Craig ${ }^{2}$
}

Additional INDEX WORds. martha washington geranium, Pelargonium xdomesticum

$\mathrm{R}$ egal pelargoniums (Pelargonium $\times$ domesticum) are one of the lesser-known relatives of the ever-popular zonal geranium $(P$. $\times$ hortorum $)$. Other relatives of both the regals and zonals are the ivy geraniums ( $P$. peltatum) and the scented geraniums (Pelargonium sp.). All the geraniums mentioned here are actually pelargoniums, and all have their origins in South Africa. Regals are not as well known as zonals, perhaps because of their poorer garden performance, yet they have persisted in the commercial trade for centuries. This is a tribute, primarily, to their splendid flowers (Fig. 1). For centuries regals have been a much-admired, if difficult to produce, potted plant with outstanding flowers. Their story begins with the Dutch trade in South Africa and travels around the globe and into the modern day realms of molecular research.

\section{Nomenclature}

Bailey (1901) first definitively described the complex hybrid group of cultivated plants known as regals. Cultivars within this group resulted from interspecific hybridization that oc-

Department of Agriculture, Western Illinois University, Macomb, IL. 61455.

This work was supported in part by funding from the Fred C. Gloeckner Foundation and the Pennsylvania State University Intercollege Graduate Program in Genetics. From a dissertation submitted by M.M. Loehrlein in partial fulfillment for the Ph.D. degree in genetics. The cost of publishing this paper was defrayed in part by the payment of page charges. Under postal regulations, this paper therefore must be hereby marked advertisement solely to indicate this fact.

${ }^{1}$ Current address: Assistant professor of horticulture, Department of Agriculture, Western Illinois University, Macomb, IL 61455.

${ }^{2}$ J. Franklin Styer Professor of Horticultural Botany, Department of Horticulture, The Pennsylvania State University, University Park, Pa. 16802. curred in The Netherlands, Germany, England and France. This breeding activity occurred after the introduction of the hooded-leaf pelargonium (P. cucullatum), which is thought to be the primary progenitor of regals (Bailey, 1901; Clifford, 1970; van der Walt and Ward-Hilhorst, 1977), to Europe from South Africa in 1690. The most complete records of these hybridizations are documented in the five volumes of Sweet's Geraniaceae (Sweet, 1820-26).

The regal pelargonium has been referred to as the regal as early as the 1870 s. They were also called royal pelargoniums in the late 1800s. Clifford (1970) reports that a cultivar Royal or Regal was available in 1833. In the 1830s regals were called pelargoniums, and thus were distinguished from the other cultivated plants of the genus, which were referred to as geraniums. In North America, regals were commonly named martha washington or lady washington geranium, show-, fancy-, or pansy-flowered geranium, and summer azalea (Liberty Hyde Bailey Hortorium, 1976). In Germany, regals were referred to as edelpelargonien (German edel $=$ royal), while in Belgium in the 1880s they were called Pelargonium grandiflorum. Species names which were unsubstantiated by taxonomic descriptions, and therefore did not gain wide usage, include $P$. Xhortulanorum, by Victor Lemoine in France, and the English P. speciosum (Clifford, 1970).

\section{Botanical classification}

The Family Geraniaceae, a member of the Order Geraniales, Subclass Rosidae(Cronquist, 1988), is comprised of five genera and 700 species (van der Walt, 1979). Genera in this family are united most notably by the beak-like capsular fruit. The largest genera (also the first ones identified) are Geranium, Erodium, and Pelargonium. Thus the respective common names refer to the fruit shape: cranesbill (Greek geranos $=$ crane), storksbill (Greek erodios $=$ stork), and heronsbill (Greekpelargos $=$ heron). The two other cultivated Geraniaceae are Sarcocaulon and Monsonia (Liberty Hyde Bailey Hortorium, 1976).

The feature which distinguishes Pelargonium, with 250 species, from the other genera is the presence of a spur which is fused to the petiole and the uppermost sepal (Cronquist, 1988). Pelargonium is comprised of herbaceous annuals, perennials and bienni- als, as well as shrubs and shrublets. Over 200 Pelargonium species are native to South Africa (van derWalt, 1993). Eighteen species occur in the rest of Africa, and eight on Australasia; there are also two on Madagascar, two in the Near East, and one each on the islands of St. Helena and Tristan de Cunha (van der Walt, 1993).

\section{Origin}

Regals do not occur in the wild, but are only known in cultivation. As many as nine species (see Genetics and Cultivar Development section) have been identified as possible contributors to the development of the regal. All nine are indigenous to South Africa, and are found primarily in the western and southwestern coastal regions and near the Cape of Good Hope (Riley, 1963). The primary progenitor is thought to be the hooded-leaf pelargonium, originally described as Geranium cucullatum by Linnaeus in 1753. The hooded-leaf pelargonium is indigenous to the coastal region of the southwestern cape of South Africa. An illustration of a plant identified as G. cucullatum was included in a catalogue published in 1687. The publisher, Paul Hermann, included 10 geraniums (later classified as Pelargonium) which had been introduced from the cape of South Africa. All ten were grown in the Leyden Botanic Garden in Holland (Webb, 1984). The hooded-leaf pelargonium was introduced to Kew Gardens in England in 1690 by Bentick

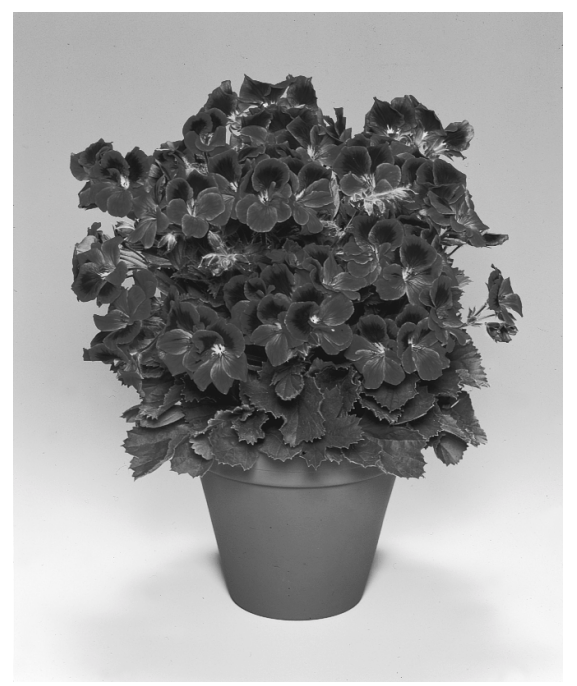

Fig. 1. Regals are known for their outstanding floral display. ('Aristo Cherry' photo courtesy of Elsner PAC Jungpflanzen, Dresden, Germany). 
(van derWaltand Ward-Hilhorst, 1977). Harvey (1860) reports its cultivation as an ornamental hedgerow plant, making it the first pelargonium on record to be used in this manner (van der Walt and Ward-Hilhorst, 1977).

\section{Anatomy}

In cultivation regals are used as a short-lived flowering potted plant. Under cool, frost-free environmental conditions it can grow into a large, shrubby, semi-woody plant. Leaves are usually simple, alternate, petiolate, obscurely lobed or denticulate, but may be palmate and divided. Various sizes and shapes of trichomes are present. Leaves, as well as inflorescences are subtended by stipules.

FLOWERS. The zygormorphic flowers are borne in a compound umbel. Flowers, measuring 1.2 to 2.4 inches $(3$ to $6 \mathrm{~cm}$ ) across, are perfect and complete. The flower bud is usually enclosed by five sepals. Flowers commonly have five petals, with the upper two occasionally larger than the lower three. While six, seven, or eight petals are not uncommon, the superfluous petals lay flat, so that a doubling effect is absent. Petals may be ruffled and often have dark-pigmented blotches or feathering, especially along the veins, which may be found on either the upper, the lower, or all petals. Many cultivars have bicolored flowers in which the upper two petals are of a different color or hue than the lower petals.

Regal flowers are known for their vivid coloration. Colors range from white to pale pink, bright crimson, mauve, deep burgundy, purple, and lavender. True red is a rare, but not unknown color in the regal pelargonium. Authors (Clifford, 1970; Erwin and Engelen, 1992; Hanniford and Riseman, 1993) usually credit the celandine-leafed pel$\operatorname{argonium}(P$. fulgidum) with contributing the red color to regals, a suggestion that probably originates with Sweet (Sweet, 1820-26).

Kato et al. (1991) investigated the inheritance of petal blotches in regals and demonstrated that five blotches are dominant over two blotches on the upper petals, and that colorless lower petals are dominant over colored ones.

Mitchell etal.(1998)demonstrated that either flavonoids or carotenoids were responsible for cream and yellow pigmentation, and anthocyanins were responsible for all other colors. The major anthocyanins identified were the 3,5-diglucosides and 3-glucoside-5(6-acetyl)glucosides of pelargonidin, cyanidin, peonidin, delphinidin, petunidin, and malvidin. Pigment variation in the petals was due to types and levels of the anthocyanins present. Where inner petals had more intense pigmentation (blotches), the level of pigmentation was 5 to 10 times that of the outer, less intense portion of the petal (Mitchell et al., 1998). Anthocyanins in the inner petals in these cases were predominantly delphinidin, petunidin and malvidin.

Reproductive organs. The androecium of regals consists of five to seven stamens with filaments united at the base. Both genotype and environmental conditions can affect pollen fertility. Some genotypes consistently produce sterile stamens, while others may produce sterile stamens when temperatures are too warm or irradiance is too low.

The gynoecium is a compound pistil having a five-lobed stigma, fused nectar tubes, and five united carpels with five locules. Each locule contains two tandem ovules, at least one of which is sterile. Placentation is exile and the ovary is superior. Each seed is contained in a papery mericarp that is attached to the style along its length. Fruit capsules contain five mericarps and are usually one-seeded. When seeds are ripe and fruit begins to dehisce, the mericarp recurves spirally from the base while adhering to the tip of the style. The inside surface of the mericarp is plumose, allowing easy wind dispersal.

\section{Genetics and cultivar development}

Genetics. The hooded-leaf pelargonium hybridizes freely in the wild with the birch-leaf pelargonium $(P$. betulinum) (van der Walt and WardHilhorst, 1977) and the large-flowered pelargonium (P.saniculaefolium) (Jackson, 1977). The latter resembles another large-flowered pelargonium $(P$. grandiflorum), and they may be synonymous (van der Walt and WardHilhorst, 1977). Gibby and Westfold (1986) reported that the large-flowered pelargonium was used in hybridization with the hooded-leaf pelargonium early in the 19th century. The large-flowered pelargonium wasintroduced to England in 1794, nearly a century after the hooded-leaf pelargonium (Harvey, 1860) had been introduced. The birchleaf pelargonium had been in cultiva- tion in England since 1786 (Harvey, 1860).

Other species that may have contributed to the genetic composition of regal cultivars are the rose-scented pelargonium ( $P$. capitatum), the heartleaved pelargonium ( $P$. cordifolium), and the celandine-leaved pelargonium (Clifford, 1970); the apricot geranium (P. scabrum), the rose geranium $(P$. graveolens) (Knicely and Walker, 1966); and $P$. angulosum (Bailey, 1901; Jackson, 1977; Langton and Runger, 1985; Riley, 1963). Pelargonium angulosum, sometimes referred to as the maple-leaf geranium ( $P$. acerifolium) has more recently been assigned as $P$. cucullatum subspecies strigifolium (Volschenk et al., 1982). Walters (1985) used the orange geranium (P. citrosum), the lemon geranium (P. crispum) and the oak-leaved geranium (P. quercifolium) in development of the Romany, Royal (sold as royalty series in the United States) and Tudor regals in the late 1900s in England.

According to van der Walt's classification (1993), the section Pelargonium, sometimes erroneously called Pelargium (van der Walt and Vorster, 1981), includes the birch-leaf pelargonium, the rose-scented geranium, the lemon-scented geranium, the heartleaved pelargonium, the hooded-leaf geranium, and the rose geranium. The large-flowered geranium (syn. $P$. saniculaefolium) belongs to the section Glaucophyllum (van derWalt and WardHilhorst, 1977) and the celandineleaved geranium belongs to the section Polyactium. The designated lectotype for the genus Pelargonium is the hoodedleaf pelargonium (van der Walt and Vorster, 1981). In a review of interspecific crossability in Pelargonium, Horn (1994) reported that species in the section Pelargonium were crossed with species in Polyactium, Hoarea, and Glaucophyllum resulting in viable seeds.

While the basic chromosome number for the section Pelargonium is $\mathrm{x}=11$ (Albers and van derWalt, 1984), Knicely and Walker (1966) found variable ploidy levels for species contributing to the development of regals. Specifically, they reported $2 \mathrm{~N}=36$ for the apricot geranium, $2 \mathrm{~N}=22$ for the celandine-leaved pelargonium, $2 \mathrm{~N}=72$ for the rose geranium, and $2 \mathrm{~N}=54$ for the rosescented pelargonium. His report differs somewhat from Albers and van der Walt (1984) for which the latter researchers report $2 \mathrm{~N}=22$ (apricot geranium), 88 
(rose geranium), and 66 (rose-scented geranium). Albers and van der Walt (1984) also report $2 \mathrm{~N}=22$ for birchleaved pelargonium, heart-leaved pelargonium, and $P$. cucullatum subsp. strigifolium. Gibby and Westfold (1986) report $2 \mathrm{~N}=22$ for the large-flowered pelargonium. Given the above chromosome counts, Albers and van der Walt (1984) concluded that the basic chromosome number in the section Pelargonium is $\mathrm{x}=11$, designating plants having $2 \mathrm{~N}=22$ as diploids, those having $2 \mathrm{~N}=66$, hexaploids, and those having $2 \mathrm{~N}=88$, octoploids.

The interspecific hybridization between species in the development of regals has contributed to the complex cytogenetics of regal cultivars. Regals are believed to be polyploids of complex parentage (Craig, 1982). Reported chromosome numbers for regal cultivars vary from $2 \mathrm{~N}=43$ and 44 (Coffin and Harney, 1978), 44 (Gauger, 1937), 45 (Takagi, 1928), to 17,18 , and 35 (Darlington and Wylie, 1955), and 36, 42 , and 45 (Knicely and Walker, 1966). Thus, aneuploidy is not uncommon among regal cultivars.

Cultivar development. Regals have been highly prized for their spectacular floral displays for many years. Flower form was often the primary focus in developing new genotypes (Bode, 1966a). Some of the common names for regals are based on various flower-types. For example, the largeflowered show pelargonium flowers were spotted, fringed and semidouble; smaller-flowered types were referred to as fancy pelargoniums (Clifford, 1970). The pansy-flowered geranium was a smaller flowering regal that usually had two upper petals with dark pigmentation while the three lower petals were white. The color pattern coupled with very rounded petals imparts on this flower a striking resemblance to the pansy (van Pelt-Wilson, 1965). 'Lady Washington' or 'Martha Washington' was an early cultivar popular in the United States (Hanniford and Holcomb, 1982).

Early hybridization efforts. German hybridizers modified the existing small-flowered type regals into the largeflowered types which also had an extended flowering period (van Pelt-Wilson, 1965). Regal cultivars developed by Carl Faiss in Germany were introduced to California in the 1920s (Schmidt, 1955). Many of these cultivars performed well and were leading cultivars of the time, including 'Grossmama Fischer' (translation: 'Grandma Fischer'), 'Fruhlingzauber' (translation: 'Spring Magic'), and 'Ostergruss' (translation: 'Easter Greeting'). Sales of Faiss' 'Marie Vogel' exceeded other regal cultivars, in all countries up to the early 1950s (Bode, 1966b). From the cross between 'Marie Vogel' and 'Beverly Fabretti' William Schmidt developed the cultivar 'Grand Slam', from which the sport 'Lavender Grand Slam' originated.

Besides William Schmidt, numerous other notable breeders in the United States introduced improved cultivars from the 1930s through the 1950s, including Ernest Robert (Bode, 1966b); R.M. Henley and Clara Sue Jarrett (Schmidt, 1955); Albert H. Cassidy and Richard Diener (Schmidt, 1956); Howard Kerrigan (Schmidt, 1956; Sefton, 1993); Fred and Alice Bode, Amanda Brown and her sons Lowell and Waverly, and Harry and Clara May (Sefton, 1993).

Current hybridization efforts. Throughout the history of regals, the breeding focus has been on flower form and color, and, to some extent, plant form: short petioles and short internodes are preferred. Many hobby breeders continue to breed beautiful plants with superior ornamental qualities. These plants are often traded or sold informally through geranium societies in various locales. More information on the work of hobbyists is available through geranium and pelargonium associations in the United States (International Geranium Society, Pasadena, Calif.), England (British Pelargonium and Geranium Society, Ilford, Essex; British and European Geranium Society, Claytonle-Woods, Chorley, Lancashire), Canada (Canadian Geranium Society, Mississauga, Ontario) and Australia (International Geranium Society, Wembley Downs, Western Australia).

Until recently, cultivars have not been developed specifically for modern greenhouse production and often exhibited several horticultural constraints. One major production limitation is the cool temperature requirement for flower induction and development. Other limitations that must be overcome for successful greenhouse production include ease of rooting, predictable flowering response, whitefly resistance, shipping ability, and postproduction quality. Currently two hybridization programs exist in the United States that are ad- dressing these problems: Oglevee, Ltd. of Connellsville, Pa., and Pennsylvania State (Penn State) University pelargonium breeding program at University Park.

Efforts to improve horticultural qualities of regals began at Penn State under the direction of Richard Craig in 1977. The first patented cultivars released from this program belong to the Elegance series: 'Allure', 'Crystal', 'Fantasy', 'Flair', 'Majestic', and 'Splendor'. The most important criteria in the development of these cultivars were predictable flowering response and improved postproduction quality. Temperatures for floral initiation were maintained at a minimum of $58^{\circ} \mathrm{F}\left(14^{\circ} \mathrm{C}\right)$ to achieve the desired flowering response in the development of new genotypes. New additions to the Elegance series have been developed both at the Penn State and at Oglevee, Ltd.: 'Tiara', 'Brilliance', 'Dandy', 'Symphony', 'Fascination', 'Enchantment', 'Sandra', 'Erin', 'Lois', 'Debutante', and 'Rapture'.

David Lemon, currently with Oglevee, Ltd., first began working on regals in 1986. Many of the cultivars he developed are included in the Maiden series: 'Maiden Lilac', 'Maiden Orange', 'Maiden Rose Pink', and 'Maiden Petticoat' are grown and marketed by Oglevee, Ltd. and were released beginning in 1996 (Oglevee, 1996). Two additional cultivars in the Maiden series were originally sold as Vavra cultivars: 'Maiden Sunrise' and 'Maiden Red'. The Vavra cultivars were originally developed by Wolfgang Kirmann in Austria and included the cultivars 'Josy', 'Dolly', 'Mary', 'Peggy', 'Macy', 'Honey', and 'Shirley'. In general, Vavra cultivars are difficult to root, require night temperatures around $60^{\circ} \mathrm{F}$ (16 ${ }^{\circ} \mathrm{C}$ ) for floral initiation and are less heattolerant than other modern cultivars (Oglevee, 1995). For these reasons many Vavra cultivars have been discontinued for sale in the United States, but are still available in Europe.

Oglevee, Ltd. also markets the Royalty series that were originally developed by Ernest Walters, a hobbyist regal breeder in England. Walters' primary goal was to develop regals with extended flowering periods. He accomplished that, along with dwarf habit, natural free-branching habit, and inflorescences held high above the foliage (Walters, 1985). While many of the original Royalty cultivars have been superseded in the United States by newer 
cultivars, the traits they exhibited have been integrated into newer cultivars. Of the original Royalty series, only the cultivar Baroness is still available through Oglevee, Ltd. David Lemon has added 'Imperial', 'Excalibur', 'Emperor', and 'Monarch' cultivars to the Royalty series, and the former Vavra cultivar 'Empress' is also now included in the Royalty series. 'Camelot' is a new addition to the Royalty series that was developed at Pennsylvania State University.

Both Richard Craig at Penn State and David Lemon at Oglevee, Ltd. continue to develop new cultivars of regals. Objectives for genetic improvement include resistance to petal abscission, elimination of cool temperature and high irradiance requirements for flowering, and greenhouse whitefly (Trialeurodesvaporariorum) resistance. Other goals include improved performance under adverse environmental conditions including heat and humidity tolerance, and improved petal tolerance to rain.

In Germany and England, two relatively new commercial programs have been initiated. Elsner pac Jungpflanzen (Dresden, Germany) is focusing on developing regals with reduced cooling requirements ( 3 to 4 weeks below $50^{\circ} \mathrm{F}$ $\left(10^{\circ} \mathrm{C}\right)$ ) for floral initiation, compact growth habit that does not require growth regulators, soft, crack-resistant foliage for better shipping performance, and uniform flowering (Andrea Michalik, personal communication). Elsner pac Jungpflanzen will market and distribute their new cultivars worldwide; they will be available in the United States through Oglevee, Ltd.

Floranova (Norfolk, England) is investigating the possibility of developing seed-raised regals having a reduced vernalization period. In addition, numerous nurseries in England specialize in regals and purchase hybrids developed by independent breeders ( $\mathrm{F}$. Brawner, personal communication).

\section{Environmental requirements}

Flowering Process. At the time of visible flower buds, all the stages of meristem ontogeny from vegetative to floral have been completed. In regals, floral ontogeny occurs in the meristem in four stages: 1) vegetative, 2) transitional, 3) early inflorescence and floral organ development, and 4) floral organ development (Loehrlein and Craig, 2000). Floral ontogenetic development is not correlated to plant growth param- eters such as number of leaf nodes, rate of leaf development, dry weight or leaf area (Loehrlein, 1997).

Regals are day-neutral plants with respect to flowering. Research conducted prior to 1980 indicated that flowering was controlled by temperature and irradiance (Crossley, 1968; Hackett and Kister, 1974; Nilsen, 1975; Post, 1942; Powell and Bunt, 1978). However, the cultivars studied are no longer economically viable or widely available. Nevertheless, even modern regal cultivars vary in response to temperature and irradiance. Furthermore, floral initiation and floral development may be thought of and treated as two separate processes, with differing requirements for optimal response during each process. For example, Hackett and Kister (1974) reported an interaction between temperature and irradiance on flowering, but did not differentiate the floral initiation process from the floral development process. Both processes may be affected by irradiance and temperature, with interactions between the two, and with variable genotypic responses.

Erwin (1991) found that when provided $8 \mathrm{~h}$ photoperiod under ambient light, 'Fanatsy' bloomed only when average daily temperatures remained at or below $61^{\circ} \mathrm{F}\left(16^{\circ} \mathrm{C}\right)$. When 'Fantasy' was provided $8 \mathrm{~h}$ ambient light at 54 , 64 , or $75^{\circ} \mathrm{F}\left(12,18\right.$, or $\left.24^{\circ} \mathrm{C}\right)$ plus $3 \mathrm{~h}$ of red lighting at $25 \mathrm{fc}\left(5 \mathrm{mmol} \cdot \mathrm{s}^{-1} \cdot \mathrm{m}^{-2}\right)$ during the first $3 \mathrm{~h}$ of night at 54 or 64 ${ }^{\circ} \mathrm{F}$, plants bloomed 4 to $13 \mathrm{~d}$ earlier than those plants which received only an $8 \mathrm{~h}$ photoperiod.

In a study on floral initiation in regals, nine cultivars were grown at four daily light integrals and constant temperature of $60^{\circ} \mathrm{F}$ (Loehrlein and Craig, 1999). They found that floral initiation could be manipulated in some cultivars. For example, 'Splendor', 'Duchess' and 'Jennifer', initiated floral meristems 27 to $47 \mathrm{~d}$ earlier as daily light integral increased from 5 to $20 \mathrm{~mol} \cdot \mathrm{d}^{-1}$. While other cultivars, including 'Fantasy' and 'Princess' initiated floral meristems in about $30 \mathrm{~d}$, regardless of daily light integral.

Powell and Bunt (1978) examined the effects of temperature and irradiance on floral development, following 7 weeks of cool pretreatment in an unheated greenhouse. Plants were then grown for 3 weeks at 50,55 , or $61^{\circ} \mathrm{F}(10$, 13 , or $16^{\circ} \mathrm{C}$ ) and then half were left and the other half were moved to $61^{\circ} \mathrm{F}$ until they flowered. Short day-treated plants were provided an 8 h day of ambient light, while long-day-treated plants received ambient lighting supplemented with tungsten lighting $\left(160 \mathrm{~J} \cdot \mathrm{cm}^{-2} \cdot \mathrm{d}^{-1}\right)$ to provide an $18 \mathrm{~h}$ photoperiod. They reported an interaction such that at the higher $\left(64^{\circ} \mathrm{F}\right)$ average temperature flowering was advanced by $36 \mathrm{~d}$ without an unacceptable reduction in flower number when irradiance was increased. They also found that at higher $\left(64^{\circ} \mathrm{F}\right)$ average temperature and short $(8 \mathrm{~h})$ days, flowers completely aborted. Erwin and Engelen (1992) also reported flower bud abortion at average daily temperatures greater than $61^{\circ} \mathrm{F}$. Therefore when day temperatures are high night temperatures must be lowered to maintain a low average daily temperature.

\section{Cultural requirements}

Propagation. Regals are vegetatively propagated because of low seed set. Several reasons include variable fertility of ovules and pollen (Stuart et al., 1993, Stuart and Jourdan, 1994), environmental effects on fertility (Stuart and Hanniford, 1990), and complex interspecific cytogenetics (Knicely, 1966). However, vegetative propagation presents an additional set of problems, including the necessity of maintaining a large supply of stock plants, poor rooting due to environmental and genetic components, and a need for stringent control of environmental and sanitation factors to prevent infection by pathogens.

Craig and Oglevee (1990) have developed protocols for successful commercial production of regals. For initiation, they recommend growing propagules at 57 to $63{ }^{\circ} \mathrm{F}$ (14 to 17.2 ${ }^{\circ} \mathrm{C}$ ) with cumulative irradiance of 350 to $425 \mathrm{~mol} \cdot \mathrm{m}^{-2}$ applied over a $28-\mathrm{d}$ period (12 to $15 \mathrm{~mol} \cdot \mathrm{m}^{-2} \cdot \mathrm{d}^{-1}$ ). Supplemental lighting is recommended to ensure a 16-h photoperiod and the minimum cumulative irradiance.

Growers typically purchase cuttings from a professional cutting producer. Rooted and nonrooted (callused) vegetative cuttings are available, as well as rooted cuttings that are pre-budded. Rooted prebudded cuttings are sold in 3 -inch $(7.5-\mathrm{cm})$ pots and require up to $60 \mathrm{~d}$ to finish a marketable plant. Rooted cuttings should flower in 12 to 14 weeks, while nonrooted, callused cuttings will require an additional 2 to 3 weeks and must be provided the appropriate environment for root development as speci- 
fied later in this section (Oglevee, 1995).

Cuttings are made by removing 2.5 to 3.0 inch $(6.4$ to $7.5 \mathrm{~cm})$ of a terminal shoot having four to six leaves. The stem should be succulent and turgid, and may be removed by hand or by using a sterilized knife or pair of clippers. Lower leaves should be removed, leaving two fully expanded leaves and the terminal growing tip (Hanniford and Holcomb, 1982). Flower buds should be removed. Two to three leaf nodes should be inserted into the rooting media.

Care must be taken when inserting the cutting, as wounding may create an infection site for botrytis (Botrytis cineria), to which regals are susceptible (Hanniford and Holcomb, 1982). Dusting the cutting with a rooting hormone compound containing a fungicide will help reduce botrytis and stimulate rooting (Hanniford and Holcomb, 1982). After potting, cuttings may be drenched with a fungicide as a preventative measure (Armitage and Kaczperski, 1992).

Commercially, cuttings are placed into Rubber Dirt plugs (Oglevee, Ltd., Connellsville, Pa.). Rubber Dirt is composed of peat moss, water, and a hydrophilic polymer. However, use of any well-drained media, with $\mathrm{pH}$ adjusted to 5.5 to 6.0 should be adequate for good root development (Oglevee, 1995).

Cuttings are placed under a mist environment for the first $3 \mathrm{~d}$, with frequent misting beginning $\mathrm{l} h$ after sunrise to $\mathrm{l} \mathrm{h}$ before sunset. In the morning apply mist at a frequency of 8 to $10 \mathrm{~s}$ every $30 \mathrm{~min}$, increasing to 8 to $10 \mathrm{~s}$ every 7 min during the heat of the day, then decrease to 8 to $10 \mathrm{~s}$ every $30 \mathrm{~min}$ towards the end of the day (Hanniford and Holcomb, 1982). Misting may be reduced to midday applications after the first week, and roots should have begun to develop (Hanniford and Holcomb, 1982). By the middle of the second week, misting may be discontinued as long as wilting does not occur.

Heating of the rooting medium at 70 to $75^{\circ} \mathrm{F}\left(21\right.$ to $\left.24^{\circ} \mathrm{C}\right)$ is necessary for the successful rooting of cuttings (Craig and Oglevee, 1990). After 2 weeks, the medium temperature may be reduced to 62 to $65^{\circ} \mathrm{F}$ ( 17 to $18^{\circ} \mathrm{C}$ ) (Craig and Oglevee, 1990). In 4 to 6 weeks plants should be adequately rooted (Hanniford and Holcomb, 1982). Rooted cuttings are then placed into the floral initiation environment recommended by Craig and Oglevee (1990).
Microtechniques. Root establishment problems may be circumvented with somatic embryogenesis. Efforts to develop this alternate propagation method with regals have been advanced by the research of Marsolais et al. (1991) and Wilson (1994). Micropropagation techniques have been researched by Cassells(1987a), Hauser(1993) Hauser et al. (1995) and Horn (1988). Propagation by callus-derived protoplasts was studied by Dunbar (1991); and in vitro culture was investigated by Nord (1989). One or several of these techniques may replace cutting propagation as the preferred method of production in the future. Reports on ovule culture of $P$. $\times$ domesticum hybrids have been given by Kato and Tokumasu (1983), and results are further described by Kato et al. $(1988,1989)$.

Genetic transformation. Boase et al. $(1996,1998)$ reported on successful Agrobacterium-mediated transformation of the regal cultivar 'Dubonnet'. The goal of their study was to transfer a range of flavonoid and plant morphology genes. Bradley et al. (1998) also successfully transformed 'Dubonnet', but failed to obtain phenotypic alteration in transformants expressing the transgene $L c$ (leaf color) of maize.

Season. Regals are sold in retail stores as flowering potted plants in the spring. They are most readily available between Easter and Mother's Day. Regals are produced in pots ranging in size from 4 to 8 inches ( 10 to $20 \mathrm{~cm}$ ). Regals are sold through florist's shops or local garden centers. Regals do not ship well, due to the tendency of petals to abscise. In favorable areas of cool night temperatures and low rainfall regals are excellent outdoor plants, particularly in containers. Petal abscission is a problem in areas of frequent rainfall or overhead watering. In coastal California they may bloom in containers nearly year-round.

Nutrition. Regals should be placed on a fertilizer program of 150 to 250 $\mathrm{ppm}\left(\mathrm{mg} \cdot \mathrm{L}^{-1}\right)$ nitrogen $(\mathrm{N})$ and potassium (K) (Hanniford and Holcomb, 1982; Artmitage and Kaczperski, 1992). Specific requirements may vary for individual cultivars and may be adjusted depending on local environment and location. Nevertheless, it is critical that recommended nutrient levels are achieved early in production. Therefore, the first watering should contain 300 to 400 ppm of N and K. Levels may then be dropped during subsequent irrigation to $100 \mathrm{ppm} \mathrm{N}$ and $\mathrm{K}$ (Erwin and Engelen, 1992).

Regals are grown under cool temperatures, so ammoniacal nitrogen should be avoided. Phosphorus, calcium, magnesium and micronutrients should be pre-mixed with the soilless media (Craig and Oglevee, 1990), and controlled release fertilizers may be used as an alternative to liquid fertilizer. For example, 14-6.2-11.6 controlled release fertilizer has been used successfully at a rate of 0.5 teaspoon $(2.4 \mathrm{~g})$ per 6 inch $(15-\mathrm{cm})$ pot at the time of transplanting and 4 weeks later (Hanniford and Holcomb, 1982). Magnesium and/ or iron deficiencies commonly occur due to high $\mathrm{pH}$ of the soilless media. Media $\mathrm{pH}$ should be maintained at or below 6.8 (Erwin and Engelen, 1992).

Regals are sensitive to soluble salts, therefore soluble salt levels should be monitored regularly (Armitage and Kaczperski, 1992). Soluble salts in the growing medium should not be allowed to exceed $0.75 \mathrm{ds} \cdot \mathrm{m}^{-1}$ (Craig and Oglevee, 1990). Soil and foliar testing should be conducted in developing an accurate fertilization regime (Oglevee, 1999).

Carbon dioxide. Specific recommendations for $\mathrm{CO}_{2}$ supplementation have not been developed. However, regals would most likely benefit from supplemental $\mathrm{CO}_{2}$ because it encourages vegetative growth (Armitage and Kaczperski, 1992).

IrRigation. Propagules should be misted regularly during the root development period. Plants should be wellwatered when first planted. Subsequently, plants should be kept adequately moist and not allowed to dry out, and excessive watering should be avoided. (Armitage and Kaczperski, 1992).

Media. Regals can be produced in a wide variety of media components. Regardless, they grow best at a $\mathrm{pH}$ of 5.5 to 6.0 in a well-drained, porous soilless media (Armitage and Kaczperski, 1992). Vermiculite should be avoided, due toits tendency to compact (Oglevee, 1999). Nonsterile media must be pasteurized to avoid problems with botrytis (Armitage and Kaczperski, 1992).

Height control. Chlormequat restricted stem growth on noncooled (uninitiated) 'Lavender Grand Slam', but had no significant effect on cooled (initiated) plants (Holcomb, 1979). Neither ancymidol nor daminozide affected stem elongation in either cooled or noncooled plants. Giberellic acid did 
not increase stem elongation of either cooled or noncooled plants.

Bonzi (paclobutrazol) at 8 to 10 ppm is effective as height control (C. Batschke, personal communication). Cycocel (46\% chlormequat chloride) sprays of 500 to 1500 ppm (Craig, 1986; Erwin and Engelen, 1992) or 3000 ppm (C. Batschke, personal communication) can be used during forcing of nonpinched regal plants. However, 2 $h$ of lighting in the middle of the dark period may be sufficient to produce the desired height control. For optimal height control, this light may be provided by high intensity discharge (HID) lamps with increased irradiance in the blue spectrum. (R. Craig, personal communication). If HID lights are used, Cycocel is not needed (Craig, 1986).

Application of zero or negative DIF (day - night temperatures = DIF), where night temperatures equal or exceed day temperatures, particularly in the first 2 to 4 h of daylight is adequate for height control of regals (Erwin and Engelen, 1992). For best results regals may be grown with equal day and night temperatures, or with 5 to $7{ }^{\circ} \mathrm{F}$ ( 3 to 5 $\left.{ }^{\circ} \mathrm{C}\right)$ warmer day than night temperatures. Application of zero or negative DIF throughout the day will result in reduced green foliage coloration (Erwin and Engelen, 1992).

Spacing. Distance between pots should equal the diameter of the pots. Therefore, 6 -inch $(15-\mathrm{cm})$ pots should be placed $1 / \mathrm{ft}^{2}\left(10.75 / \mathrm{m}^{2}\right)$, while 4 inch pots may be placed $2.5 / \mathrm{ft}^{2}(26.87 /$ $\mathrm{m}^{2}$ ) (Craig and Oglevee, 1990).

Pinching and disbudding. Plants may be pinched when transplanted to encourage side shoots and produce a larger finished plant (Armitage and Kaczperski, 1992). Plants should be pinched after rooting and before floral initiation (Craig and Oglevee, 1990; Armitage and Kaczperski, 1992). When pinching is used, the crop is delayed by 2 to 3 weeks (Craig and Oglevee, 1990).

\section{Diseases and insects}

InSECT PESTs. Mealy bugs (Planococcus citri, Pseudococcus sp.), aphids (Myzus persicae, Aphis gossypii), mites (Tetranychus urticae), thrips (Frankliniana occidentalis), and greenhouse whiteflies are common pests of regals (Hanniford and Holcomb, 1982; Craig, 1989). Among these, the greenhouse whitefly is the major pest affecting regals (Hanniford and Holcomb, 1982; Adams, 1987).
Castañé and Albajes (1992) found that the adult greenhouse whitefly has a preference for regal cultivars with larger leaves and fewer trichomes. This suggests potential for genetic selection in developing whitefly-resistant cultivars. Until that occurs, however, use of a systemic insecticide or other control method is recommended to ensure long-lasting pest control.

Pathogens. Regals are a carriers for bacterial blight (Xanthomonas campestris pvr. pelargonii), which can devastate geraniums. Bacterial blight causes a vascular wilt in zonals (Knaus and Tammen, 1967).

Leaf spot (Alternaria alternatai) (Fletcher, 1984), grey mold (Botrytis cinerea), black stem rot (Pythium splendens) (Fletcher, 1984; Horst, 1990), verticillium wilt (Verticillium alboatrum and $V$.dabliae) (Fletcher, 1984), Rbizoctonia (Erwin and Engelen, 1992) and viruses also affect regals (Craig, 1989). Crown gall (Agrobacterium tumefaciens) and leafy gall (Corynebacterium fascians) occur on occasion (Fletcher, 1984). Geranium rust (Puccinia pelargonii) can be a serious problem in geraniums. Rust resistant cultivars of regals do exist, however (McCoy, 1975).

The most effective, and sometimes the only control for diseases on regals is to use disease-free cuttings from culture and virus indexed sources (Fletcher, 1984; Horst, 1990). Incidences of botrytis may be avoided by proper plant spacing, reducing or eliminating overhead watering, and by speedy removal of all infected plants or plant parts (Horst, 1990).

Serological and bioassay tests can be conducted to detect the presence of pathogens (Cassells, 1987b), including in vitro screening of bacterial blight (Dunbar and Stevens, 1989). A sophisticated method has been developed to produce disease-indexed propagules, combining culture indexing, heat treatment of culture-indexed material, virus-indexing, and a combination of bioassays and enzyme-linked immunosorbent assay (ELISA) tests (Craig and Oglevee, 1990; Oglevee, 1995). The availability of clean stock has eliminated virus diseases as a major problem of regals (Fletcher, 1984). The use of culture- and virus-indexing for pathogens is the most reliable method developed to ensure clean stock of all propagules. This is especially important for growers who culti- vate both zonal geraniums and regals.

\section{Physiological disorders}

Oedema is a nonparasitic disease related to insufficient water loss from the leaves. Oedema usually affects ivyleaved geraniums, but can occur on regals as well (Fletcher, 1984). Regals do not perform well outdoors in temperate continental climates. Flowering is inhibited by high night temperatures in summer. Rain contributes to petal abscission. However, in coastal areas where cool night temperatures prevail, regals grow and bloom freely (Post, 1949; Hanniford and Holcomb, 1982). Smaller-flowered types perform better outdoors and are not as susceptible to botrytis infection (D. Lemon, personal communication).

\section{Postharvest}

Petal abscission is a problem during postharvest and is accentuated by high temperature, low light, and ethylene (Post, 1949; Deneke et al., 1990; Armitage and Kaczperski, 1992). As a matter fact, regals are among the most responsive species to ethylene (Deneke et al., 1990). Forcing temperature also contributes to flower petal abscission, such that lower temperatures during forcing resulted in fewer petals abscising during and subsequent to shipping (Evensen and Olson, 1992). For example, rooted cuttings forced for 4 weeks in a controlled environment growth chamber at $64 / 55^{\circ} \mathrm{F}(18 / 13$ $\left.{ }^{\circ} \mathrm{C}\right)$ day/night versus $70 / 61{ }^{\circ} \mathrm{F}(21 /$ $16^{\circ} \mathrm{C}$ ) day/ night for 18 -h photoperiods prolonged by $5 \mathrm{~d}$ the floral display in a postproduction environment (Evensen and Olson, 1992).

Silver thiosulfate (STS) reduced ethylene sensitivity of regal florets and increased longevity of florets that reached anthesis when applied to plants in the bud stage (Deneke et al., 1990). However, increased incidences of Pythium have been shown to be related to STS on zonal geraniums (Hausbeck et al., 1987), rendering it of little use in regal production. Currently STS is not registered for regals.

Since regal flower buds are not sensitive to ethylene, shipping-related petal abscission could be reduced if regal plants were shipped during the bud stage. 1-Methylcyclopropene (MCP) may prove to be a viable alternative as an ethylene block (Serek et al., 1995). However, sufficient research has not been conducted on regals to 
determine the benefits and possible disadvantages.

Plants do not perform well under low-light conditions such as those found inside buildings. Plants should be placed in an area receiving adequate light of at least 6 to $12 \mathrm{fc}$ (30 to 60 $\mu \mathrm{mol} \cdot \mathrm{s}^{-1} \cdot \mathrm{m}^{-2}$ ) (Olson and Evensen, 1990), moderate temperatures, and good ventilation to help reduce ethylene buildup (Craig and Oglevee, 1990).

\section{Harvest stage}

Potted plants are marketable when petal color is visible but flower buds are not yet ready to open. Since most regal flowering plants are produced and sold close to the retail outlets, timing of shipments can be accurately controlled. Some garden centers and nurseries sell at the production location.

Although regals perform well outdoors in some geographical regions, their commercial potential may long remain in the potted plant sales arena. It remains to be seen whether the genetics are present, or can be introduced from yet other species, for the desired outdoor performance in humid regions of moderate to high rainfall, or in regions where warm nights in summer are common. Until such improvements are made, though, regals may continue to have a special niche in the marketplace for their bold, if temporary beauty for centuries to come.

\section{Literature cited}

Adams, R. 1987. Regal geraniums (martha washington geraniums) Pelargonium $\times$ domesticum. GrowerTalks 51(6):10-11.

Albers, F. and J.J.A. van der Walt. 1984. Untersuchungen zur karyologie und mikrosporogenese von Pelargonium sect. Pelargonium (Geraniaceae). Pl. Syst. Evol. p. 147, 177-188.

Armitage, A.M. and M. Kaczperski. 1992. Seed-propagated geraniums and regal geraniums. Timber Press Portland, Ore.

Bailey, L.H. 1901. Cyclopedia of american horticulture. Cornell Univ. Press, Ithaca, N.Y.

Boase, M.R., S.C. Deroles, C.S. Winefield, S.M. Butcher, N.K. Borst, and R.C. Butler. 1996. Genetic transformation of regal pelargonium (Pelargonium $\times$ domesticum 'Dubonnet') by Agrobacterium tumefaciens. Plant Sci. 121:47-61.

Boase, M.R., J.M. Bradley, and N.K. Borst.
1998. An improved method for transformation of regal pelargonium (Pelargonium $\times$ domesticum 'Dubonnet') by Agrobacterium tumefaciens. Plant Sci. 139(1):5969.

Bode, F.A. 1966a. Character study of a queen. Geraniums around the world 8(4):76-81, 95.

Bode, F.A. 1966b. Character study of a queen. Part II. Geraniums around the world $9(2): 28-35$.

Bradley, J.M., S.C. Deroles, M.R. Boase, S. Bloor, E. Swinny, and K.M. Davies. 1998. Variation in the ability of the maize $L c$ regulatory gene to upregulate flavonoid biosynthesis in heterologous systems. Plant Sci. 140:31-39.

Cassells, A.C. 1987a. Adventitious regeneration in Pelargonium $\times$ domesticum Bailey. Acta Hort. 212:419-425.

Cassells, A.C. 1987b. Problems posed by cultivable bacterial endophytes in the establishment of axenic cultures of Pelargonium $\times$ domesticum: the use of Xanthomonas pelargonii specific ELISA, DNA probes, and culture indexing in the screening of antibiotic treated and untreated donor plants. Acta Hort. 225:153-161.

Castañé, C. and R. Albajes 1992. Pelargonium cultivar selection by adults of greenhouse whitefly (Homoptera: Aleyrodidae). Environ. Entomol. 21(2):269-275.

Clifford, D. 1970. Pelargoniums, including the popular 'Geranium'. Blandford Press, Chatham, England.

Coffin and Harney. 1978. Intersubgeneric crosses of Pelargonium genus. Euphytica 27:567-576.

Craig, R. 1982. Chromosomes, genes and cultivar improvement, p. 380-410. In: J.W. Mastalerz and E.J. Holcomb (eds.). Geraniums III. Pa. Flower Growers, Univ. Park, Pa.

Craig, R. 1986. Regal and ivy leaved geraniums. Bedding Plant News 17(6):6-10.

Craig, R. and J.R. Oglevee. 1990. Precision flowering of regal pelargoniums ( $\mathrm{Pel}$ argonium $\times$ domesticum). Process patent \#4,897,957.U.S. Patent and Trademark Office. Wash., D.C.

Cronquist, A. 1988. The evolution and classification of flowering plants. 2nd ed. N.Y. Botanical Garden, New York.

Crossley, J.H. 1968. Warm vs. cool short days as preconditions for flowering of $\mathrm{Pel}$ argonium $\times$ domesticum cultivars. Can J. Plant Sci. 48:211-212.

Darlington, C.D. and A.D. Wylie. 1955. Chromosome atlas of flowering plants. Allen and Unwin, Ltd., London.
Deneke, C.F., K.B. Evensen, and R. Craig. 1990. Regulation of petal abscission in Pelargonium $\times$ domesticum. HortScience 25(8):937-940.

Dunbar, K.B. 1991. Plant regeneration from callus-derived protoplasts of Pelargonium $\times$ domesticum. Plant Cell Rpt. 10(8):417-420.

Dunbar K.B. and C.T. Stevens. 1989. An in vitro screen for detecting resistance in Pelargonium somaclones to bacterial blight of geranium. Plant Dis. 73:910-12.

Erwin, J. 1991.Cool temperatures are still critical on regals. Minn. Comm. Flower Growers Assn. Bul. 40(3):3-4.

Erwin, J. and G. Engelen. 1992. Regal geranium production. Minn. Comm. Flower Growers Assn. Bul. 41(6):1-9.

Evensen, K.B. and K.M. Olson. 1992. Forcing temperature affects postproduction quality, dark respiration rate, and ethylene responsiveness of Pelargonium $\times$ domesticum. J. Amer. Soc. Hort . Sci. 117(4):596-599.

Fletcher, J.T. 1984. Disease of greenhouse plants. Longman group Ltd., New York.

Gauger, W. 1937. Ergebnisse einer zytologischen untersuchung der familie Geraniaceae. I. Planta 26:529-531.

Gibby, M. and J. Westfold. 1986. A cytological study of Pelargonium sect. Eumorpha (Geraniaceae). Plant Sys. Evol. 153:205-222.

Hackett, W.P. and J. Kister. 1974. Environmental factors affecting flowering in Pelargonium $\times$ domesticum cultivars. J. Amer. Soc. Hort. Sci. 99(1):15-17.

Hanniford, G.G. and E.J. Holcomb. 1982. Regal geraniums, p. 161-169. In: J.W. Mastalerz and E.J. Holcomb (eds.). Geraniums III. Pa. Flower Growers Assn., Univ. Park, Pa.

Hanniford, G.G. and A. Riseman. 1993. Regal geraniums, p. 175-190. In: J.White (ed.). Geraniums IV. Ball Publishing, Geneva, Ill.

Harvey, W.H. 1860. Geraniaceae. In W.H. Harvey and O.W. Sonders (eds.). Flora capensis 1:254-308.

Hausbeck, M.K., C.T. Stevens, and R.D. Heins. 1987. Variation in resistance of geraniums to Pythium ultimum in presence or absence of silver thiosulfate. HortScience 22:940-43.

Hauser, B. 1993. Mikrovermehrung von Pelargonium Grandiflorum hybriden. Gartenbauwissenschaft 58(6):251.

Hauser, B., C. Leinmuller, and F. Walz. 1995. Mikrovermehrung von Pelargonium Grandiflorum hybriden II. Effect of macro 
salts, gelling agent, and closure of test tube. Gartenbauwissenschaft 60(2):62-65.

Holcomb, E.J. 1979. Effect of growth regulators on noncooled and cooled Pelargonium $\times$ domesticum. HortScience 14(3):280-281.

Horn, W. 1988. Micropropagation of Pelargonium $\times$ domesticum Pelargonium $\times$ domesticumhybrids. Acta Hort. 226:5358 .

Horn, W. 1994. Interspecific crossability and inheritance in Pelargonium. Plant Breeding 113:3-17.

Horst, R.K. 1990. Westcott's plant disease handbook $5^{\text {th }}$ ed. Chapman and Hall, New York

Jackson, W.P.U. 1977. Wildflowers of Table Mountain. Howard Timmins Publ., Cape Town, South Africa.

Kato, M., M. Fujikoa, and F. Kakihara. 1991. Histological observations of petals and inheritance of blotches in Pelargonium $\times$ domesticum L.H. Bailey. Mem. Coll. Agr. Ehime Univ. 35:147-159.

Kato, M., M. Fujikoa, F. Kakihara, and S. Tokumasu. 1988. Flowering characteristics of hybrids between regal and scentedleaved geraniums in Pelargonium. Mem. Coll. Agr. Ehime Univ. 32:101-109.

Kato, M., M. Fujikoa, F. Kakihara, and S. Tokumasu. 1989. Improvement of flower color of regal geranium (Pelargonium $\times$ domesticum) by means of interspecific hybridization. Proc. $6^{\text {th }}$ Intl. Congr. of SABRAO. p. $455-458$

Kato, M. and S. Tokumasu. 1983. Characteristics of $\mathrm{F}_{1}$ hybrids produced by ovule culture in ornamental Pelargonium. Acta Hort. 131:247-52.

Knaus, J.F. and J. Tammen. 1967. Resistance of Pelargonium to Xanthamonas pergonii. Phytopathology 57:1178-1181.

Knicely, W.W. and D.E. Walker. 1966. Chromosome numbers and crossability studies in the genus Pelargonium. Proc. Intl. Hort. Congr. Abstr. 209.

Langton, F.A. and W. Runger. 1985. Pelargonium, p. 9-21. In CRC handbook of flowering. vol. IV. CRC Press, Boca Raton, Fla.

Liberty Hyde Bailey Hortorium. 1976. Hortus third: A concise dictionary of plants cultivated in the United States and Canada. 3rd ed. Macmillan, New York.

Loehrlein, M.M. 1997. Floral ontogeny of Pelargonium $\times$ domesticum and response of floral initiation to irradiance. PhD diss. Pa. State University. University Park.

Loehrlein, M.M. and R. Craig. 1999. Floral initiation of regal pelargonium grown at varying daily light integrals. HortScience 34(3):539 (abstr.).

Loehrlein, M.M. and R. Craig. 2000. Floral ontogeny of Pelargonium $\times$ domesticum. J. Amer. Soc. Hort. Sci. 125(1):36-40.

Marsolais, A.A., D.P.M. Wilson, M.J. Tsujita, and T. Senaratna. 1991. Somatic embryogenesis and artificial seed production in Zonal (Pelargonium $\times$ hortorum) and Regal (Pelargonium $\times$ domesticum) geranium. Can. J. Bot. 69:1188-1193.

McCoy, R. 1975. Susceptibility of pelargonium species to geranium rust. Plant Dis. Rpt. 59:618-20.

Mitchell, K. A., K. R. Markham and M. R. Boase. 1998. Pigment chemistry and colour of Pelargonium flowers. Phytochemistry. 47:355-61.

Nilsen, J.H. 1975. Factors affecting flowering in regal pelargoniums (Pelargonium xdomesticum Bailey). Acta Hort. 51:299_ 309

Nord, S.M. 1989. An in vitro germplasm preservation system for Pelargonium $\times$ domesticum. MS thesis. Ohio Sate Univ., Columbus.

Oglevee. 1995. Catalog. Oglevee Ltd. Connellsville, $\mathrm{Pa}$.

Oglevee. 1996. Oglevee on-line catalog 12/14/00. <http://www.oglevee.com/ articles/new_crops.htm>

Oglevee. 1999. Catalog. Oglevee Ltd. Connellsville, PA.

Olson, K.M. and K.B. Evensen. 1990. The influence of irradiance on ethylene sensitivity and postproduction quality of Pelargonium $\times$ domesticum. Acta Hort. 181:25762.

Post, K. 1942. Effects of daylength and temperature on growth and flowering of some florist's crops. Cornell Agr. Expt. Sta. Bul. 787. Ithaca, N.Y.

Post, K. 1949. Florist Crop Production and Marketing. Orange Judd Pub. Co., Inc., New York, N.Y.

Powell, M.C. and A.C. Bunt. 1978. Effect of temperatures and light on flower development in Pelargonium $\times$ domesticum. Scientia Hort. 8(1978):75-79.

Riley, H.P. 1963. Families of flowering plants of southern Africa. Univ. Kentucky Press, Lexington.

Schmidt, W.E. 1955. Pelargonium breeders I have known. Geraniums around the world 3(3):56-15.

Schmidt, W.E. 1956. Pelargonium domesticum: originators, varieties, and dates of introduction. Geraniums around the world 4(1):8-10.
Sefton, J.E. 1993. A regal reunion, or, calling the class of ' 60 . Geraniums around the world $41(4): 6-13$.

Serek, M., G. Tamari, and E.C. Sisler. 1995. Inhibition of ethylene-induced cellular senescence symptoms by 1 methylcyclopropene, a new inhibitor of ethylene action. Physiologia Plantarum 94:229-32.

Stuart, M. and G. Hanniford. 1990. Effects of supplemental lighting and genotype on fertility of Pelargonium $\times$ domesticum. HortScience 25(9):1173 (abstr.)

Stuart, M., G. Hanniford, and P. Jourdan. 1993. Variation in male fertility of Pelargonium $\times$ domesticum. HortScience 28(5):483 (abstr.).

Stuart, M. and P. Jourdan. 1994. Pistil influence on growth of pollen tubes of $P$. $\times$ domesticum. HortScience 29(5):496 (abstr.).

Sweet, R. 1820-26. Geraniaceae. 5 Volumes, London.

Takagi, F. 1928. On the chromosome numbers of Pelargonium. Sci. Rpt. Tohoku Univ., Ser. 4. Biol. 3. p. 665-671.

van der Walt, J.J.A. 1979. Pelargoniums of Southern Africa. vol I. $2^{\text {nd }}$ ed. Pallotinerdruck, Limburg, South Africa.

van der Walt, J.J.A. 1993. Discovering the world of pelargoniums. Proc. 3rd Intl. Geranium Conf. Ball Publ., Batavia, Ill.

van der Walt, J.J.A. and P.J. Vorster. 1981. Typification of the genus Pelargonium L'Herit. (fam. Geraniaceae). Taxon 30:307.

van der Walt, J.J.A. and E. Ward-Hilhorst. 1977. Pelargoniums of Southern Africa. Purnell \& Sons, Ltd. Cape Town, South Africa.

van Pelt Wilson, H. 1965. The joy of geraniums. Wm. Morrow \& Co., New York.

Volschenk, B., J.J.A van der Walt, and P.J. Vorster. 1982. The subspecies of Pelargonium cucullatum (Geraniaceae). Bothania. 14(1):45-51.

Walters, E. 1985. New developments in pelargoniums. The Garden 110(8):3713 .

Webb, W.J. 1984. The Pelargonium family. Croom Helm, London.

Wilson, D.P.M. 1994. Histology of somatic embryogenesis in regal geranium. J. Amer. Soc. Hort. Sci. 119(3):648-651. 